\title{
HUBUNGAN PERAN KELOMPOK DUKUNGAN SEBAYA DENGAN KUALITAS HIDUP ORANG HIV/AIDS (ODHA) DI POLI VCT RSUD SYARIFAH AMBAMI RATO EBU BANGKALAN
}

\author{
${\text { Mufarika1, } \text { Fitriah}^{2} \text {, Siti Aisyah }}^{1}$
}

1. Dosen Pengajar Prodi S1 Keperawatan STIKES Ngudia Husada Madura

2. Dosen Pengajar Prodi Kebidanan Poltekes Kemenkes Surabaya

E-mail: mufarika.unpad@gmail.com

\begin{abstract}
Abstrak
AIDS dapat diartikan sebagai kumpulan gejala atau penyakit yang disebabkan oleh menurunnya kekebalan tubuh akibat infeksi virus HIV yang termasuk famili retroviridae. Kualitas hidup ODHA menjadi sangat rentan mengalami penurunan akibat masalah baik fisik, psikologis, maupun sosial. Penelitian ini bertujuan untuk menganalisis hubungan peran kelompok dukungan sebaya dengan kualitas hidup pada orang dengan HIV/AIDS (ODHA). Jenis penelitian yang digunakan yaitu analitik dengan menggunakan pendekatan Cross Sectional. Sampel dalam penelitian ini sebanyak 61 responden. Pengambilan sampel menggunakan Simple random sampling. Instrumen yang digunakan adalah kuesioner. Data dianalisis menggunakan uji statistik Spearman Rank. Hasil penelitian menunjukkan bahwa hampir seluruhnya mendapatkan peran kelompok dukungan sebaya kurang yaitu 46 (75\%) ODHA. Hasil uji statistik menunjukkan nilai $p$ value $(0,000)<\alpha(0,05)$, artinya ada hubungan peran kelompok dukungan sebaya dengan kualitas hidup pada orang dengan HIV/AIDS (ODHA) di Poli VCT RSUD Syarifah Ambami Rato Ebu Bangkalan.
\end{abstract}

Kata Kunci: Kualitas Hidup, Peran Kelompok Dukungan Sebaya, AIDS

\begin{abstract}
AIDS can be interpreted as a collection of symptoms or diseases caused by decreased immunity due to infection with the HIV virus belonging to the family of retroviridae. The quality of life of people living with HIV becomes very susceptible to decrease due to physical, psychological, and social problems. This study aimed to analyze the relationship of peer support group roles to the quality of life in people with HIV / AIDS (ODHA). The type of research used was analytical using Cross Sectional approach. The sample in this research were 61 respondents. Sampling using Simple random. The instrument used was a questionnaire. The data were analyzed using Spearman Rank statistic test. The results showed that almost entirely received less peer support group roles of 46 (75\%) of people living with HIV. The result of statistical test showed the value of $p$ value $(0,000)<\alpha(0,05)$, meaning there was relation of peer support group role with quality of life in people with HIV /AIDS (ODHA) in Poly VCT Syarifah Ambami Rato Ebu Bangkalan Hospital.
\end{abstract}

Keywords: Quality of Life, The Role of Peer Support Groups, AIDS 


\section{PENDAHULUAN}

HIV (Human immunodeficiency Virus) merupakan virus yang menyerang kekebalan tubuh manusia, sedangkan AIDS (Acquired Immunodeficiency Syndrome) adalah sindrom kekebalan tubuh oleh infeksi HIV (Noviana, 2013). Orang dengan HIV/AIDS (ODHA) yang tidak mampu melakukan aktifitas seharihari mengindikasikan bahwa penderita mengalami penurunan kualitas hidup (Suryono \& Nasronudin, 2014).

Sejak pertama ditemukan, HIV/AIDS menyebabkan berbagai respon seperti penolakan, ketakutan, stigma dan diskriminasi yang menyebabkan terjadinya kecemasan dan prasangka terhadap ODHA (Frederikson, 2007).

Adanya stigma dan diskriminasi yang berujung pada ketidaksetaraan dalam kehidupan sosial dapat membuat dengan HIV/AIDS (ODHA) menjadi sulit membuka diri dan bersosialisasi. Sehingga hal ini akan semakin menghambat ODHA untuk berkontribusi dilingkungan sosialnya. Semakin berkurangnya peran fungsi dalam masyarakat akan semakin memicu penurunan kualitas hidup ODHA. Sehingga perlu intervensi yang dapat membantu ODHA untuk menunjang kualitas hidup yang lebih baik. Kualitas hidup merupakan kemampuan individu dalam menikmati kepuasan selama hidupnya (Ventegodt, 2008).

Data menurut United Nations Programme on HIV/AIDS 2014 di dunia terdapat sebanyak 36,9 juta orang dengan HIV, dan 1,5 juta meninggal dalam keadaan AIDS (Rozi, 2016). Data kemenkes RI (2015) pada tahun 2010-2012 jumlah kasus baru HIV positif di Indonesia cukup stabil. Tahun 2010 jumlah kasus baru HIV positif sebesar 21.591 kasus kemudian meningkat secara signifikan pada tahun 2014 yaitu sebesar 32.711 kasus baru. Tercatat bahwa pada tahun 2013 - 2014 kasus HIV mengalami peningkatan secara signifikan. Peningkatan jumlah kasus baru AIDS selalu terjadi setiap tahunnya. Jumlah kumulatif kasus AIDS sampai dengan akhir 2014 sebesar 65.790 kasus (Gunawan, 2017).

Sementara jumlah survailens di poli VCT RSUD Syarifah Ambami Rato Ebu Bangkalan pada bulan November-Desember 2016 sebanyak 5 orang. Pada bulan Januari-November 2017 sebanyak 67 orang. Berdasarkan studi pendahuluan 10 responden di poli VCT RSUD Syarifah Ambami Rato Ebu Bangkalan didapatkan 5 orang dengan kualitas hidup buruk yaitu ODHA masih mengalami keterbatasan dalam beraktifitas, sering memiliki perasaan putus asa, tidak puas dengan dirinya sendiri dan merasa dikucilkan dari lingkungan sosialnya. Kemudian terdapat 2 orang dengan kualitas hidup sedang yaitu ODHA puas terhadap kemampuannya untuk bekerja, masih dapat menerima penampilan tubuhnya, puas terhadap hubungan sosialnya dan merasakan aman dalam kehidupan sehari-hari. Selanjutnya 2 orang dengan kualitas hidup baik yaitu ODHA merasa masih membutuhkan terapi medis untuk dapat berfungsi dalam kehidupan sehari-hari, puas dalam menikmati hidup dan puas terhadap kehidupan seksual. Selain itu terdapat 1 orang dengan kualitas hidup yang sangat baik yaitu ODHA memiliki vitalitas yang baik untuk beraktifitas sehari-hari, merasa hidupnya sangat berarti, dapat menerima dengan keadaan dirinya 
yang sekarang dan sering memiliki kesempatan untuk rekreasi. Buruknya kualitas hidup orang dengan HIV/AIDS (ODHA) diukur menggunakan empat dimensi yaitu fisik, psikologi, lingkungan dan sosial. Kesimpulan dari data tersebut masih banyaknya responden dengan kualitas hidup buruk di poli VCT RSUD Syarifah Ambami Rato Ebu Bangkalan.

Kualitas hidup ODHA dipengaruhi oleh fisik, level ketergantungan ARV, lingkungan, dukungan sebaya dan spiritual (Rasyid, 2016). Domain kualitas hidup dibagi menjadi domain fisik, psikologi, hubungan sosial dan lingkungan. Kualitas hidup terendah adalah domain lingkungan dan hubungan sosial sehingga kondisi hidup menurun dan mengakibatkan kualitas hidup juga menurun (Hardiansyah, 2014). Dijelaskan bahwa terdapat faktor-faktor lain yang dapat mempengaruhi kualitas hidup pada pasien HIV yaitu infeksi, terapi antiretroviral, dukungan sosial, jumlah CD4, kepatuhan pengobatan, pekerjaan, gender, gejala, depresi dan lingkungan keluarga (Disa, 2014)

Salah satu faktor yang memiliki peranan penting dalam meningkatkan kualitas hidup ODHA adalah kelompok dukungan sebaya. Dukungan sebaya diartikan sebagai suatu kenyamanan, perhatian, penghargaan, atau bantuan yang dirasakan ODHA dari orang lain atau sesama ODHA. Pola dukungan kelompok sebaya dimulai dengan pertemuan tertutup bagi ODHA untuk saling berbagi pengalaman, ketakutan dan harapan. Pola pun berkembang dengan kegiatan belajar bersama hingga keterlibatan ODHA lebih luas dalam penyebaran informasi dan advokasi terkait HIV

(Rasyid, 2016)

\section{METODE PENELITIAN}

Pada penelitian ini populasi yang digunakan adalah orang dengan HIV/AIDS (ODHA) di Poli VCT RSUD Syarifah Ambami Rato Ebu Bangkalan sebanyak 72 orang dengan sampel 61 orang. Dalam penelitian ini tekhnik pengambilan sampel menggunakan Simple random sampling. Data dikumpulkan dengan menggunakan kuesioner. Kuesioner yang digunakan yaitu kuesioner peran kelompok dukungan sebaya dan kuesioner kualitas hidup. Diuji dengan uji statistik Spearman Rank didapat nilai signifikansinya $<0,05$ maka $\mathrm{H}_{0}$ ditolak berarti terdapat Hubungan Peran Kelompok Dukungan Sebaya dengan Kualitas Hidup orang dengan HIV/AIDS (ODHA).

\section{HASIL PENELITIAN}

\section{Data Umum}

Tabel 1 Distribusi Frekuensi Berdasarkan Karakteristik Responden di poli VCT RSUD Syarifah Ambami Rato Ebu Bangkalan

\begin{tabular}{|c|c|c|c|}
\hline No & $\begin{array}{c}\text { Jenis } \\
\text { kelamin } \\
\end{array}$ & Frekuensi & $\begin{array}{c}\text { Presentase } \\
(\%)\end{array}$ \\
\hline 1 & Laki - laki & 28 & 46 \\
\hline \multirow[t]{2}{*}{2} & Perempuan & 33 & 54 \\
\hline & Jumlah & 61 & 100 \\
\hline No. & Usia & Frekuensi & $\begin{array}{c}\text { Presentase } \\
(\%)\end{array}$ \\
\hline 1 & $\begin{array}{l}\text { Remaja } \\
\text { akhir (17- } \\
\text { 25) tahun }\end{array}$ & 12 & 20 \\
\hline 2 & $\begin{array}{l}\text { Dewasa } \\
\text { awal (26- } \\
\text { 35) tahun }\end{array}$ & 9 & 15 \\
\hline 3 & $\begin{array}{l}\text { Dewasa } \\
\text { akhir (36- } \\
\text { 45) tahun }\end{array}$ & 32 & 52 \\
\hline
\end{tabular}


Lansia awal

$4 \quad$ (46-55)

8

13

tahun

\begin{tabular}{|c|c|c|c|}
\hline & Jumlah & 61 & 100 \\
\hline No. & Pendidikan & Frekuensi & $\begin{array}{c}\text { Presentase } \\
(\%)\end{array}$ \\
\hline 1 & $\begin{array}{c}\text { Tidak } \\
\text { sekolah }\end{array}$ & 12 & 20 \\
\hline 2 & SD & 32 & 52 \\
\hline 3 & SMP & 7 & 11 \\
\hline 4 & SMA & 6 & 10 \\
\hline \multirow[t]{2}{*}{5} & $\begin{array}{l}\text { Perguruan } \\
\text { tinggi }\end{array}$ & 4 & 7 \\
\hline & Jumlah & 61 & 100 \\
\hline No. & $\begin{array}{c}\text { Lama } \\
\text { Menderita }\end{array}$ & Frekuensi & $\begin{array}{c}\text { Presentase } \\
(\%)\end{array}$ \\
\hline 1 & $<1$ tahun & 14 & 23 \\
\hline 2 & 1-3 tahun & 47 & 77 \\
\hline \multirow[t]{2}{*}{3} & $>3$ tahun & 0 & 0 \\
\hline & Jumlah & 61 & 100 \\
\hline
\end{tabular}

Diketahui bahwa jenis kelamin responden sebagian besar perempuan yaitu 33 (54\%) responden. Sebagian besar berusia 36-45 tahun yaitu sebanyak 32 (52\%) responden. Sebagian besar berpendidikan sekolah dasar yaitu $32(52 \%)$ responden. Hampir seluruhnya menderita HIV/AIDS selama 1-3 tahun yaitu 47 (77\%) responden.

\section{Data Khusus}

Tabel 2 Distribusi frekuensi berdasarkan peran kelompok dukungan sebaya di Poli VCT RSUD Syarifah Ambami Rato Ebu Bangkalan

\begin{tabular}{clcc}
\hline No. & $\begin{array}{c}\text { Peran Kelompok } \\
\text { Dukungan Sebaya }\end{array}$ & Frekuensi & $(\boldsymbol{\%})$ \\
\hline 1 & $\begin{array}{l}\text { Peran kelompok } \\
\text { dukungan sebaya baik } \\
2\end{array}$ & 5 & 8 \\
$\begin{array}{l}\text { Peran kelompok } \\
\text { dukungan sebaya } \\
\text { cukup }\end{array}$ & 10 & 17 \\
3 & $\begin{array}{l}\text { Peran kelompok } \\
\text { dukungan sebaya } \\
\text { kurang }\end{array}$ & 46 & 75 \\
\hline & Jumlah & 61 & 100 \\
\hline
\end{tabular}

Diketahui bahwa hampir seluruhnya dari responden mendapatkan peran kelompok dukungan sebaya kurang yaitu $46 \quad$ (75\%) responden.

Tabel 3 Distribusi frekuensi berdasarkan kualitas hidup pada orang dengan HIV/AIDS (ODHA) di Poli VCT RSUD Syarifah Ambami Rato Ebu Bangkalan

\begin{tabular}{clcc}
\hline No. & \multicolumn{1}{c}{ Kualitas Hidup } & Frekuensi & $(\boldsymbol{\%})$ \\
\hline 1 & $\begin{array}{l}\text { Kualias hidup sangat } \\
\text { baik }\end{array}$ & 2 & 3 \\
2 & Kualitas hidup baik & 7 & 11 \\
3 & Kualitas hidup sedang & 14 & 24 \\
4 & $\begin{array}{l}\text { Kualitas hidup buruk } \\
5\end{array}$ & 27 & 44 \\
Kualitas hidup sangat & 11 & 18 \\
\hline & Jumlah & 61 & 100 \\
\hline
\end{tabular}

Diketahui bahwa hampir setengahnya dari responden mengalami kualitas hidup buruk yaitu 27 (44\%) responden.

Tabel 4 Tabulasi silang peran kelompok dukungan sebaya dengan kualitas hidup pada orang dengan HIV/AIDS (ODHA) di Poli VCT RSUD Syarifah Ambami Rato Ebu Bangkalan

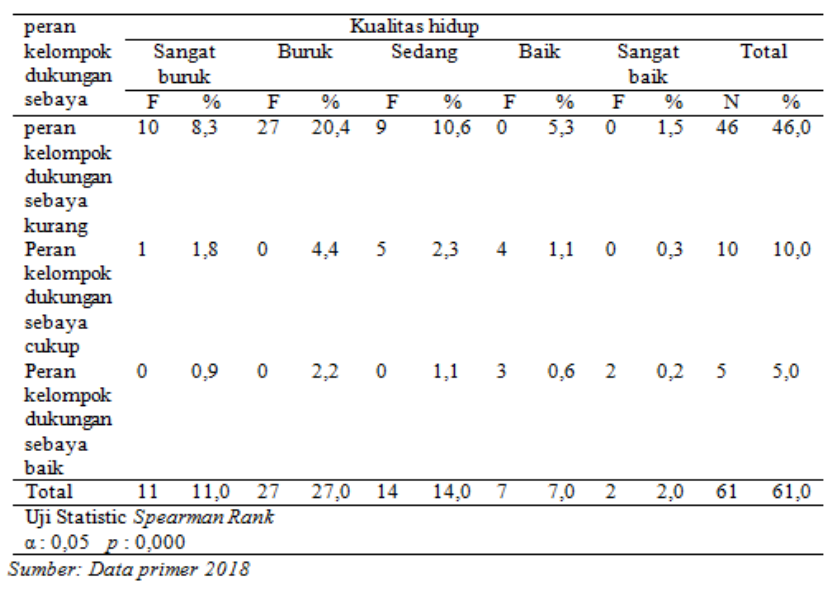

Dapat disimpulkan bahwa responden yang mendapatkan peran kelompok dukungan sebaya kurang yaitu sebanyak $46 \quad(75 \%)$ responden, 10 responden mengalami kualitas hidup sangat buruk, 27 responden mengalami 
kualitas hidup buruk dan 9 responden mengalami kualitas hidup sedang. Sedangkan kualitas hidup pada responden hampir setengahnya mengalami kualitas hidup buruk yaitu sebanyak 46 (75\%) responden.

Hasil uji statistik spearman rank diperoleh nilai $p$ value $(0,000)$ dengan tingkat kemaknaan $\alpha(0,05)$, berarti nilai $p$ value $<\alpha$. Dengan demikian dapat disimpulkan bahwa $\mathrm{H}_{0}$ ditolak yang berarti "ada hubungan peran kelompok dukungan sebaya dengan kualitas hidup pada orang dengan HIV/AIDS (ODHA) di Poli VCT RSUD Syarifah Ambami Rato Ebu Bangakalan".

\section{PEMBAHASAN}

Ada hubungan peran kelompok dukungan sebaya dengan kualitas hidup pada orang dengan HIV/AIDS (ODHA). Hal ini sesuai dengan penelitian yang dilakukan oleh Rasyid (2016) yang menyatakan bahwa terdapat hubungan positif antara peran kelompok dukungan sebaya dengan quality of life pada ODHA. Pada tabel 3 bahwa frekuensi responden yang mendapatkan peran kelompok dukungan kurang dan mengalami kualitas hidup buruk. kelompok dukungan sebaya memiliki peranan dalam mengurangi dampak sosial ekonomi HIV/AIDS pada ODHA. Secara rutin setiap 1 bulan sekali ODHA melakukan pertemuan untuk memberikan informasi dan pengetahuan terbaru terkait HIV/AIDS melalui pertemuan kelompok dukungan sebaya ini ODHA diajak berdiskusi terkait permasalahan yang sering dihadapi ODHA misalnya kesulitan ODHA untuk bisa membuka status HIV nya kepada keluarga pertemuan inilah yang secara tidak langsung ODHA akan mendapatkan dukungan baik dari keluarga, teman sebaya maupun tim medis, namun dukungan sebaya dalam kelompok dukungan sebaya tidak begitu saja tersedia, dikarenakan beberapa keterbatasan dari ODHA itu sendiri seperti sifat tertutup ODHA, komunikasi, tempat tinggal dari anggota ODHA. Adanya keterbatasan ini mengakibatkan kepercayaan dan solidaritas untuk mendukung sesama kurang. Kurang nya dukungan sebaya dapat membuat ODHA tidak ingin berinteraksi sosial, merasa kurang dihargai oleh lingkungannya, hal ini secara tidak langsung akan membuat ODHA jatuh pada kondisi stres serta akan berimbas pada penurunan kualitas hidupnya. Hal ini didukung oleh teori Rozi (2016) kurang nya peran kelompok dukungan sebaya ini akan mengantarkan ODHA pada kondisi stres, depresi, putus asa dan menutup diri, ODHA akan lebih memilih untuk merahasiakan status kesehatannya dari keluarga, teman maupun kerabatnya, sehingga ODHA pun tidak mampu mendapatkan dukungan yang seharusnya diperoleh. Kompleksnya masalah yang mesti dihadapi oleh ODHA ini tentunya dapat berimbas pada penurunan kualitas hidup khususnya pada domain psikologi. Adanya stigma dan diskriminasi yang berujung pada ketidaksetaraan dalam kehidupan sosial yang membuat ODHA menjadi tertutup untuk membuka diri dan bersosialisasi dilingkungan sekitar juga akan menghambat ODHA untuk berfungsi dalam lingkungan sosialnya. Hal ini secara tidak langsung dapat memicu penurunan kualitas hidup pada ODHA. 
Mufarika, Fitriah, Siti Aisyah, Hubungan Peran Kelompok..

Sedangkan ODHA yang mengalami kualitas hidup sedang cenderung mendapatkan peran kelompok dukungan sebaya cukup, hal ini terjadi karena ODHA merasa dengan bergabungnya menjadi anggota kelompok dukungan sebaya mampu memberikan pengetahuan dan informasi tentang penyakitnya, meskipun ODHA belum sepenuhnya terbuka dan saling mensupport antar sesama anggota. Adanya stigma dan diskriminasi buruk yang melekat pada diri ODHA sehingga ODHA merasa tidak ingin status HIV nya diketahui orang lain, karena takut adanya penolakan dari lingkungan bahkan dari anggota kelurganya (Diatmi, 2014).

Stigma pada pasien HIV AIDS dianggap sebagai masalah yang terus-menerus dan menyudutkan dalam kelompok pasien HIV AIDS. Selain menghancurkan kehidupan keluarga, sosial, dan ekonomi individu, stigma HIV AIDS dianggap sebagai penghalang utama untuk mengakses layanan pencegahan, perawatan, dan perawatan (Mahajan et al., 2008). Sehingga diperlukan dengan adanya peran kelompok dukungan sebaya yang cukup akan menunjang kualitas hidup ODHA khususnya dalam domain fisik karena dengan bergabungnya ODHA dengan KDS ODHA lebih mengetahui kebutuhan gizi yang baik untuk dirinya sehingga ODHA dijauhkan dari penyakit penyerta yang akan memperparah kondisi sakitnya, berbeda hal nya dalam domain lingkungan dan hubungan sosial meskipun sudah tergabung dengan KDS ODHA tidak ingin berkomunikasi dengan orang baru karena khawatir status HIV nya diketahui orang banyak, dengan begitu dukungan dalam KDS masih kurang terbentuk (Margawati, 2015).

Sedangkan ODHA yang mengalami kualitas hidup baik cenderung mendapatkan peran kelompok dukungan sebaya baik, hal ini terjadi karena dengan bergabung nya ODHA pada KDS akan mengurangi stigma baik dari diri sendiri maupun lingkungannya, mendapatkan informasi dan pengetahuan yang cukup untuk ODHA sehingga ODHA mampu menyelesaikan permasalahan kesehatannya sendiri, adanya perasaan senasib dari ODHA sehingga ODHA saling memberikan dukungan antar sesama ODHA, menjadi wadah kegiatan yang bermanfaat bagi ODHA seperti konseling, dan acara-acara keagamaan yang membuat ODHA lebih mendekatkan diri kepada sang pencipta sehingga ODHA tidak merasakan depresi dan feeling blues. Terpenuhinya peran kelompok dukungan sebaya ini mencerminkan adanya dukungan sosial yang baik bagi ODHA sehingga ODHA merasa dihargai, dicintai yang akan berdampak positif bagi kehidupannya.

Peran kelompok dukungan sebaya yang baik ODHA dapat meningkatkan kualitas hidup ODHA misalnya dengan peran kelompok dukungan sebaya baik memantau terapi pengobatannya khususnya ARV serta dapat menjadi tempat konseling serta penyuluhan tentang gizi yang baik bagi ODHA sehingga dapat terpenuhi secara optimal pemenuhan gizi pada ODHA dengan demikian ODHA mampu bekerja tanpa khawatir kondisi fisik nya dan ODHA lebih produktif. Selain itu, dengan peran kelompok dukungan sebaya yang baik ODHA diberikan kesempatan untuk bertemu dan berteman dengan 
orang lain sehingga ODHA merasa memiliki teman untuk berbagi, memiki perasaan senasib sehingga akan muncul dukungan saling memberikan semangat antar ODHA, sehingga ODHA tidak akan merasa sendiri sehingga terus menerus akan memikirkan penyakitnya kemudian ODHA akan jatuh pada kondisi stress yang akan memperburuk kondisi kesehatannya.

Terwujudnya dampak dukungan psikologis yang positif terhadap diri subjek, menjadikan subjek terhindar dari stress. Hal tersebut memberikan dampak positif terhadap kesehatan subjek, sehingga subjek merasa lebih sehat, tidak mudah lelah dan tidak mudah sakit. Selain itu pun, dalam memerangi virus HIV, sebjek menjadi lebih menjaga kesehatannya dengan minum obat secara teratur, makan tepat waktu, selalu berusaha menghindari pemakaian obat-obatan terlarang dan secara rutin mengkonsultasikan masalah kesehatannya ke dokter (Nurbani, 2015).

Hal ini didukung oleh teori Diatmi (2014) menyatakan bahwa kelompok dukungan sebaya memiliki peran yang sangat penting bagi kualitas hidup ODHA. Memberikan informasi terkait dengan pelayanan kesehatan, dukungan emosional dan pendampingan bagi ODHA yang memiliki masalah dengan kesehatannya, memberikan pengetahuan bagi keluarga agar bisa mmeberikan dukungan emosional kepada ODHA serta pelayanan medis yang memadai serta memberikan pengembangan pengetahuan lainnya yang dapat menunjang kualitas hidup nya.

\section{KESIMPULAN}

Ada hubungan peran kelompok dukungan sebaya dengan kualitas hidup pada orang dengan HIV/AIDS (ODHA) di Poli VCT RSUD Syarifah Ambami Rato Ebu Bangkalan. Dan kelompok dukungan sebaya efektif dalam menurunkan stigma negatif pada pasien HIV AIDS.

\section{DAFTAR RUJUKAN}

Diatmi, Komang dan Fridari, Diah 2014. Hubungan Antara Dukungan Sosial dengan Kualitas Hidup Pada Orang Dengan HIV dan AIDS (ODHA) Di Yayasan Spirit Paramacitta. Skripsi Program Studi Psikologi Universitas Udayana. Diakses pada tanggal 7 November 2017

Frederikson, J and Kanabus. 2007. A HIV/AIDS Stigmam and discrimination. Available on: http $/ /$ www.avert.org/aidsstigma.htm, Diakses pada tanggal 07 November 2017. Gunawan, Yudhi Tri. 2017. Hubungan Karakterikstik ODHA Dengan Kejadian Loss To Follow Up Terapi ARV Di Kabupaten Jember. Skripsi Peminatan Epidemiologi Fakultas Kesehatan Masyarakat Universitas Jember. Diakses pada tanggal 29 November 2017

Hardiansyah. 2016. Kualitas Hidup Orang Dengan HIV dan AIDS Di kota Makassar. Skripsi Fakultas Kesehatan Masyarakat Universitas Hasanuddin. Diakses pada tanggal 10 November 2017

Mahajan, A. P., Sayles, J. N., Patel, V. A., Remien, R. H., Sawires, S. R., Ortiz, D. J., ... Coates, T. J. (2008). Stigma in the HIV/AIDS epidemic: a review of the literature and recommendations for the way forward. AIDS, 22(Suppl 2), S57-S65. http://doi.org/10.1097/01.aids.0000327438. $\underline{13291.62}$

Margawati, K., \& Hargono, A. (2015). Perilaku seksual berisiko penularan hiv pada tenaga kerja bongkar muat di pelabuhan kalimas surabaya. Promkes, 183-194. 
Noviana., Nana. 2013 Catatan Kuliah Kesehatan Reproduksi \& HIV AIDS. Jakarta: Trans Info Media

Nurbani, F. (2015). Dukungan Sosial dan ODHA. Universitas Gunadarma, Jakarta, 1-11.

Rasyid, Astika. 2016. Pengaruh Kelompok Dukungan Sebaya Terhadap Depresi dan Quality Of life pada orang dengan human immune deficiency virus/acquired immune deficiency syndrome di Kediri Jawa Timur Masters thesis Universitas Sebelas Maret. Diakses pada tanggal 7 November 2017

Rozi, Rahdatu Fakanur. 2016. Hubungan Dukungan Sosial Dengan Kualitas Hidup ODHA Pada Kelompok Dukungan Sebaya Solo Plus Di Surakarta. Skripsi Fakultas Ilmu Kesehatan Universitas Muhammadiyah Surakarta. Diakses pada tanggal 7 November 2017

Suryono, \& Nasronudin. (2014). Clinical Description and Diagnosis of HIV / AIDS. Indonesian Journal of Tropical and Infectious Disease, 5(1), 23-27. http $/ /$ doi.org/10.1109/csnt.2014.137

Ventegodt, S., Ventegodt, S., Ventegodt, S., Ventegodt, S., Andersen, N. J., Ventegodt, S., ... Merrick, J. (2008). Quality of working life: Improving working-life quality, quality of life and health in companies. International Journal on Disability and Human Development, $\quad 7(2), \quad$ 165-184. http://doi.org/10.1515/IJDHD.2008.7.2.165 